\title{
LA ACCIÓN POPULAR EN ASUNTOS MEDIOAMBIENTALES
}

\author{
MIQUEL PONS PORTELLA \\ miquel.pons@garrigues.com
}

\begin{abstract}
Cómo citar/Citation
Pons Portella, M. (2018).

La acción popular en asuntos medioambientales. Revista de Administración Pública, 206, 179-209. doi: https://doi.org/10.18042/cepc/rap.206.06
\end{abstract}

\section{Resumen}

El Convenio de Aarhus de 1998, sobre acceso a la información, participación del público en la toma de decisiones y acceso a la justicia en materia de medio ambiente, fue incorporado al ordenamiento jurídico espańol mediante la Ley 27/2006, de 18 de julio, cuyos arts. 22 y 23 regulan la acción popular en asuntos medioambientales. Durante la última década, este instrumento procesal ha sido empleado frecuentemente para llevar ante los tribunales múltiples actos administrativos con incidencia en el medio ambiente: sanciones, concesiones, planes y reglamentos, permisos de investigación e incluso un indulto. De este modo, la Sala Tercera del Tribunal Supremo ha podido concretar las principales características de esta acción, cuyo análisis —legal, doctrinal y jurisprudencial — es el objeto del presente trabajo.

\section{Palabras clave}

Jurisdicción contencioso-administrativa; procedimiento administrativo; acción popular; medio ambiente; Convenio de Aarhus.

\section{Abstract}

1998 Aarhus Convention, on access to information, public participation in decision-making and access to justice in environmental matters, was incorporated into the Spanish legal system by means of Law 27/2006, of July 18, whose arts. 22 and 23 regulate the popular action in environmental matters. During the last decade, 
this litigation instrument has been used frequently to bring before Courts multiple administrative acts with an impact on the environment: sanctions, concessions, plans and regulations, investigation authorizations and even a pardon. In this way, Supreme Court's Contentious-administrative Chamber has been able to specify the main characteristics of this action, whose analysis - legal, doctrinal and jurisprudentialis the object of this paper.

\section{Keywords}

Contentious-administrative jurisdiction; administrative procedure; popular action; environment; Aarhus Convention. 


\section{SUMARIO}

I. INTRODUCCIÓN: 1. El art. 9.3 del Convenio de Aarhus y su desarrollo normativo. 2. Planteamiento del estudio. II. CARACTERIZACIÓN GENERAL DEL INSTITUTO: 1. Delimitación con otros supuestos de legitimación. 2. El alcance de la acción. III. DEFINICIÓN DEL CONCEPTO «ASUNTOS MEDIOAMBIENTALES». IV. LOS SUJETOS DE LA ACCIÓN POPULAR EN ASUNTOS MEDIOAMBIENTALES: 1. La problemática del beneficio de asistencia jurídica gratuita. V. CONCLUSIÓN.

\section{INTRODUCCIÓN'}

El prestigioso magistrado Rafael de Mendizábal Allende pronosticaba en 2012 que «el próximo e inmediato estirón de lo contencioso-administrativo se producirá en el terreno de la legitimación activa» ${ }^{2}$ y que "esa ampliación de quienes pueden pedir» vendrá «de la mano de la calidad de vida, aspiración situada en primer plano por el preámbulo de la Constitución que, a su vez, en el texto articulado, intenta configurarse como un derecho, cuya violación comporta una responsabilidad que puede convertirse en penal. El medio ambiente parece ser el marco, aunque no se identifiquen ambas nociones ${ }^{3}$.

Ciertamente, el preámbulo de la Constitución de 27 de diciembre de 1978 proclama la voluntad de la nación española de «promover el progreso de la cultura y de la economía para asegurar a todos una digna calidad de vida" y, de un modo más concreto, en su art. 45.1 reconoce que «todos tienen el derecho a disfrutar de un medio ambiente adecuado para el desarrollo de la

1 A lo largo de este trabajo van a emplearse las abreviaturas y las siglas que se compendian en los apéndices 1 y 2 de S. Muñoz Machado (dir.) (2017), Libro de estilo de la justicia, Barcelona: Espasa, Madrid: Real Academia Española y Consejo General del Poder Judicial.

2 R. de Mendizábal Allende (2012), La Guerra de los jueces: Tribunal Supremo vs. Tribunal Constitucional, Madrid: Dykinson, 2012, pág. 257.

3 R. de Mendizábal Allende (2012: 259). 
persona, así como el deber de conservarlo» ${ }^{4}$. Es verdad que dicho precepto se encuadra en el capítulo relativo a "los principios rectores de la política social y económica». Sin embargo, tales disposiciones, pese a girar bajo esta rúbrica:

[...] no constituyen - afirmaría con verbo brillante la Sala Tercera del Tribunal Supremo en su Sentencia de 25 de abril de 1989—- meras normas programáticas que limiten su eficacia al campo de la retórica política o de la inútil semántica propia de las afirmaciones demagógicas. Porque como ya precisó hace años el Tribunal Supremo norteamericano, en el caso Trop contra Duller, «las declaraciones de la Constitución no son adagios gastados por el tiempo; ni una contraseña vacía de sentido. Son principios vitales, vivos que otorgan y limitan los poderes del Gobierno de nuestra nación. Son regulaciones de Gobierno»" 5 . Y esta doctrina, aunque establecida por un Tribunal extranjero con referencia a la Constitución de su país, es perfectamente trasladable a nuestro ámbito. De manera que ese art. 45, como los demás del expresado capítulo, tienen valor normativo y vinculan a los poderes públicos, cada uno en su respectiva esfera, a hacerlos eficazmente operativos $\left(\mathrm{FJ} 3^{\circ}\right)$.

Así las cosas, la Ley 27/2006, de 18 de julio, por la que se regulan los derechos de acceso a la información, de participación pública y de acceso a la justicia en materia de medio ambiente afirma, en el primer párrafo de su exposición de motivos, que el sobredicho precepto constitucional «configura el medio ambiente como un bien jurídico de cuyo disfrute son titulares todos los ciudadanos y cuya conservación es una obligación que comparten los poderes públicos y la sociedad en su conjunto». Por ello, prosigue su argumentación el

4 El mismo art. 45, en su apdo. 2, dispone que «los poderes públicos velarán por la utilización racional de todos los recursos naturales, con el fin de proteger y mejorar la calidad de la vida y defender y restaurar el medio ambiente, apoyándose en la indispensable solidaridad colectiva». A su vez, en el apdo. 3, como recuerda Rafael de Mendizábal, previene que, "para quienes violen lo dispuesto en el apartado anterior, en los términos que la ley fije se establecerán sanciones penales o, en su caso, administrativas, así como la obligación de reparar el daño causado».

5 A.-C. Pereira Menaut (2010), El ejemplo constitucional de Inglaterra, México: UNAM, Instituto de Investigaciones Jurídicas, pág. 31. En el asunto Trop v. Dulles, 356 U.S. 86 (1958), la Corte Suprema de los Estados Unidos declara inconstitucional — por contrariar la Octava Enmienda: «excessive bail shall not be required, nor excessive fines imposed, nor cruel and unusual punishments inflicted»— la pena de pérdida de la nacionalidad norteamericana. El fragmento original reza del siguiente modo: «the provisions of the Constitution are not time-worn adages or hollow shibboleths. They are vital, living principles that authorize and limit governmental powers in our Nation. They are the rules of government». 
legislador, «todos tienen el derecho a exigir a los poderes públicos que adopten las medidas necesarias para garantizar la adecuada protección del medio ambiente, para disfrutar del derecho a vivir en un medio ambiente sano». Entonces, "para que los ciudadanos, individual o colectivamente, puedan participar en esa tarea de protección de forma real y efectiva, resulta necesario disponer de los medios instrumentales adecuados, cobrando hoy especial significación la participación en el proceso de toma de decisiones públicas», que es lo que regula - como se deduce de su propio título- dicha ley. Más concretamente, el objeto de la aludida Ley 27/2006 es —en palabras de la Sala de lo Contencioso-administrativo del Tribunal Supremo- «definir un marco jurídico que responda a los compromisos asumidos con la ratificación del Convenio de Aarhus y la trasposición al ordenamiento interno de Directivas comunitarias, que a su vez incorporan para el conjunto de la Unión Europea las obligaciones derivadas del Convenio» ${ }^{6}$.

Dos décadas atrás, en efecto, la Comisión Económica de las Naciones Unidas para Europa, «reconociendo que una protección adecuada del medio ambiente es esencial para el bienestar humano, así como para el goce de los derechos fundamentales, en particular el derecho a la vida», aprobó el Convenio sobre el acceso a la información, la participación del público en la toma de decisiones y el acceso a la justicia en materia de medio ambiente, hecho en Aarhus (Dinamarca) el 25 de junio de 19987. España lo ratificó por Instrumento de 15 de diciembre de 2004, mientras que la Unión Europea lo celebró por Decisión 2005/370/CE del Consejo, de 17 de febrero; ${ }^{8}$ se halla vigente desde el 29 de marzo de 2005. El Convenio de Aarhus - como lo denominaremos en adelante- declara que «toda persona tiene el derecho a vivir en un medio ambiente que le permita garantizar su salud y su bienestar, y el deber,

Sentencia de 8 de junio de 2015 (FJ 3º); Sentencia de 7 de julio de 2017 (FJ 5o).

7 Sobre el proceso de elaboración del Convenio que estudiamos, véase C. Plaza Martín (2005), Derecho ambiental de la Unión Europea, Valencia: Tirant lo Blanch, págs. 391 392, nota 1063.

8 Por ello, como apuntaba el fragmento jurisprudencial antes transcrito, serían aprobadas sucesivamente la Directiva 2003/4/CE, del Parlamento Europeo y del Consejo, de 28 de enero de 2003, sobre el acceso del público a la información ambiental y por la que se deroga la Directiva 90/313/CEE, del Consejo; y la Directiva 2003/35/CE, del Parlamento Europeo y del Consejo, de 26 de mayo de 2003, por la que se establecen medidas para la participación del público en determinados planes y programas relacionados con el medio ambiente y por la que se modifican, en lo que se refiere a la participación pública y el acceso a la justicia, las directivas 85/337/CEE y 96/61/CE. Sobre el papel del Tribunal de Justicia de la Unión Europea al respecto, véase C. Plaza Martín (2005: 411-419). 
tanto individualmente como en asociación con otros, de proteger y mejorar el medio ambiente en interés de las generaciones presentes y futuras». Pero «para estar en condiciones de hacer valer este derecho y de cumplir con ese deber", argumenta el mismo convenio en su preámbulo, «los ciudadanos deben tener acceso a la información, estar facultados para participar en la toma de decisiones y tener acceso a la justicia en materia medioambiental»?

Así pues, el art. 1 del Convenio de Aarhus dispone que, «a fin de contribuir a proteger el derecho de cada persona, de las generaciones presentes y futuras, a vivir en un medio ambiente que permita garantizar su salud y su bienestar, cada Parte garantizará los derechos de acceso a la información sobre el medio ambiente, la participación del público en la toma de decisiones y el acceso a la justicia en materia medioambiental de conformidad con las disposiciones del presente Convenio». Su art. 9, dedicado precisamente al «acceso a la justicia», prevé en el apdo. 3 que:

[...] cada Parte velará por que los miembros del público que reúnan los eventuales criterios previstos por su derecho interno puedan entablar procedimientos administrativos o judiciales para impugnar las acciones u omisiones de particulares o de autoridades públicas que vulneren las disposiciones del derecho medioambiental nacional]. Son [público], conforme al art. 2.4 del mismo convenio [una o varias personas físicas o jurídicas y, con arreglo a la legislación o la costumbre del país, las asociaciones, organizaciones o grupos constituidos por esas personas.

De este modo se delimita la acción popular en asuntos medioambientales: fundada en el art. 9.3 del Convenio de Aarhus, como queda indicado, se regula en el título IV de la Ley 27/2006, de 18 de julio, que pasamos a analizar seguidamente.

\section{EL ART. 9.3 DEL CONVENIO DE AARHUS Y SU DESARROLLO NORMATIVO}

Efectivamente, la Ley 27/2006, bajo la rúbrica «acceso a la justicia y a la tutela administrativa en asuntos medioambientales», incorpora — según leemos en su exposición de motivos- «la previsión del artículo 9.3 del Conve-

9 Sobre la debida identificación de los llamados tres "pilares» del Convenio de Aarhus, véase la Sentencia de 23 de octubre de 2014, FJ 4º. Según A. Betancor Rodríguez (2014), Derecho ambiental, Las Rozas: La Ley, pág. 361, estos tres pilares verdaderamente «son vías o medios que han de contribuir a la protección del derecho de las personas a vivir en un medio ambiente adecuado». 
nio de Aarhus» mediante la introducción de «una especie de acción popular» regulada por su art. 22, intitulado precisamente «acción popular en asuntos medioambientales», y prevista para recurrir «a través de los procedimientos de recurso regulados en el Título VII de la LRJPAC, así como a través del recurso contencioso-administrativo previsto en la LJCA». Su "ejercicio — seguimos leyendo en la exposición de motivos de la Ley 27/2006 - corresponde a las personas jurídicas sin ánimo de lucro dedicadas a la protección del medio ambiente, que se hubieran constituido legalmente al menos dos años antes del ejercicio de la acción y desarrollen su actividad en el ámbito territorial afectado por el acto u omisión impugnados»; todo ello de conformidad con el art. 23.1 de la Ley que venimos comentando, intitulado sintéticamente «legitimación». De esta manera, concluye la tan citada exposición de motivos, «se consagra definitivamente [...] una legitimación legal para tutelar un interés difuso como es la protección del medio ambiente a favor de aquellas organizaciones cuyo objeto social es, precisamente, la tutela de los recursos naturales». Todo ello, sin embargo, no nos debe hacer olvidar que, según el art. 96.1 de la Constitución de 1978, «los tratados internacionales válidamente celebrados, una vez publicados oficialmente en Espańa, formarán parte del ordenamiento interno ${ }^{10}$. Por ello, en su Sentencia de 25 de junio de 2008, la Sala Tercera del Tribunal Supremo aplicó directamente el Convenio de Aarhus en un asunto sucedido con anterioridad a la entrada en vigor de la Ley 27/2006 (FJ 50) ${ }^{11}$. $\mathrm{Al}$ poco tiempo, en Sentencia de 31 de marzo de 2009, reiteraría que el art. 9 del Convenio "vincula al órgano judicial que resuelva recursos contenciosoadministrativos en materia de medio ambiente» (FJ 50). En este mismo sentido, en su reciente Sentencia de 7 de julio de 2017, el Alto Tribunal ha insistido en que:

10 Sentencia de 8 de junio de 2015 (FJ 30).

11 Lo hizo en los términos siguientes: «al haberse negado la legitimación a la asociación recurrente, debe considerarse infringido el citado art. 9, en relación con el 2.5, del Convenio de Aarhus. Hemos de añadir que el mismo Convenio [...] fue transpuesto al derecho interno espańol [...] a través de la Ley 27/2006, de 18 de julio, que no se encontraba en vigor (pues entró en fecha de 20 de julio de 2006) cuando se dictaron los actos impugnados [...], pero sí lo estaba cuando se dictaron los Autos que ahora se impugnan. Luego la vulneración ha de proclamarse no solo del art. 9 del Convenio de Aarhus, sino también del art. 23 de la citada Ley 27/2006» (FJ 5º). En realidad, los arts. 22 y 23 de la Ley 27/2006 entraron en vigor el 19 de octubre de 2006, de conformidad con la disposición final $8^{a}$ de dicha Ley. Véase también la Sentencia de 25 de mayo de 2010: «en la fecha en que se dicta la Sentencia impugnada (24 de enero de 2006), no se encontraba en vigor la citada Ley 27/2006, de 18 de julio, pero sí el citado art. 9 del Convenio de Aarhus» (FJ 4º). 
El art. 30.1 de la Ley 25/2014, de 27 de noviembre, de Tratados y otros Acuerdos Internacionales establece la aplicación directa [de los tratados internacionales], a menos que de su texto se desprenda que dicha aplicación queda condicionada a la aprobación de las leyes o disposiciones reglamentarias pertinentes. En este caso, el art. 9.3 del Convenio de Aarhus ha quedado reflejado, no en su totalidad, en el art. 22 de la Ley 27/2006, de 18 de julio. El art. 31 de la Ley 25/2014 dispone que «las normas jurídicas contenidas en los tratados internacionales válidamente celebrados y publicados oficialmente prevalecerán sobre cualquier otra norma del ordenamiento interno en caso de conflicto con ellas, salvo las normas de rango constitucional» y, si bien no existe conflicto con lo previsto en la Ley 27/2006, la Sentencia recurrida debió interpretar [...], de conformidad con el Convenio de Aarhus y la Ley 27/2006, que la Fundación Oceana era "persona interesada» en un procedimiento administrativo relativo a la protección del medio ambiente (art. 2.5 del Convenio Aarhus y art. 2.2 de la Ley 27/2006) [FJ 6º, apdo. $\mathrm{C})]^{12}$.

Ahora bien, uno de los primeros pronunciamientos del Tribunal de Justicia de la Unión Europea sobre el art. 9.3 del Convenio de Aarhus — su Sentencia de 8 de marzo de 2011 (asunto C-240/09) — sirvió justamente para apreciar que carece de efecto directo —o sea: que no contiene «ninguna obligación clara y precisa que determine directamente la situación jurídica de los particulares»-: "dado que solamente "los miembros del público que reúnan los eventuales criterios previstos por [el] derecho interno" son titulares de los derechos previstos en el citado precepto, tal disposición se subordina, en su ejecución o en sus efectos, a la adopción de un acto ulterior» (apdo. 45). Aunque esto no obsta a que, según el propio Tribunal, cada órgano jurisdiccional deba:

[...] interpretar, en la medida de lo posible, el régimen procesal de los requisitos necesarios para interponer un recurso administrativo o judicial de manera conforme tanto a los objetivos del art. 9, apartado 3, del Convenio de Aarhus como al objetivo de garantizar la tutela judicial efectiva de los derechos

12 La conclusión que se alcanza en este caso es que «debe atenderse a lo previsto en el Convenio de Aarhus al ser parte también de nuestro ordenamiento jurídico. Y, en base a lo previsto en su art. 9.3, la Fundación Oceana estaba legitimada para impugnar la actividad de la Administración puesto que el objeto de dicha impugnación era un procedimiento abierto por una infracción cometida a una disposición de derecho ambiental por unos buques que causaron una serie de daños al medio marino» [FJ 6º, apartado C)]. De un modo parecido, la Sala también ha empleado los "presupuestos inspiradores» de Aarhus en sus Sentencias de 20 de febrero de 2010 (FJ 2o) y de 30 de junio de 2015 (FJ 2o). 
que confiere el ordenamiento jurídico de la Unión, a fin de permitir a una organización de defensa del medio ambiente [...] impugnar ante los tribunales una decisión adoptada mediante un procedimiento administrativo que pudiera ser contrario al Derecho medioambiental de la Unión (apdo. 51).

Coetáneamente, en su Sentencia de 12 de mayo de 2011 (asunto C-115/09), el mismo Tribunal de Justicia precisaría que, «si bien es cierto que corresponde a los Estados miembros determinar, cuando es así su sistema jurídico, cuáles son los derechos cuya vulneración puede dar lugar a un recurso en materia de medio ambiente, [...] no lo es menos que estos Estados no pueden privar a las asociaciones de defensa del medio ambiente [...] de la posibilidad de desempeñar el papel que les reconocen», entre otras normas, el Convenio de Aarhus (apdo. 44).

Partiendo de estas premisas, en su reciente Sentencia de 20 de diciembre de 2017, el mismo Tribunal de Justicia ha reiterado que, pese a su falta de efecto directo, el art. 9.3 del Convenio de Aarhus, «en relación con el art. 47 de la Carta [de los Derechos Fundamentales de la Unión Europea], impone a los Estados miembros la obligación de garantizar la tutela judicial efectiva de los derechos conferidos por el Derecho de la Unión, en particular de las disposiciones del Derecho medioambiental» (apdo. 45). La doctrina ha aplaudido este pronunciamiento considerándolo "extraordinario» en la medida en que hace "una clara interpretación pro actione y pro defensa de la legitimación y participación de las ONGs ambientales en los procesos relativos a autorizaciones de proyectos que tengan una incidencia sobre el medio ambiente, tanto para participar como parte interesada como para reconocer la posibilidad de recurso en vía administrativa como judicial a la luz del Convenio de Aarhus y del Derecho ambiental de la Unión» ${ }^{13}$. Destacamos al respecto cómo el Tribunal explica que el "derecho de recurso" establecido por el precepto que estudiamos «resultaría privado de todo efecto útil, e incluso de su propia esencia, si, como consecuencia de la imposición de tales criterios, se negara todo derecho de recurso a determinadas categorías de "miembros del público", en especial a los "miembros del público interesado", como las organizaciones de defensa del medio ambiente que reúnan los requisitos establecidos en el art. 2, apartado 5, del Convenio de Aarhus» (apdo. 46). Ciertamente:

[...] la imposición de los referidos criterios no puede privar a las organizaciones de defensa del medio ambiente de la posibilidad de instar el control del respeto

13 Véase este comentario del profesor Ángel Ruiz de Apodaca Espinosa en el siguiente enlace: https://bit.ly/2tPHMGi (consultado el 6 de marzo de 2018). 
de las normas del Derecho medioambiental de la Unión, toda vez que, además, tales normas se orientan en la mayoría de los casos a la protección del interés general y no a la mera protección de los intereses de los particulares de manera individual y que dichas organizaciones tienen como misión defender el interés general [...]. En efecto, los términos «eventuales criterios previstos por su derecho interno", que figuran en el art. 9, apartado 3, del Convenio de Aarhus, si bien implican que los Estados miembros conservan una facultad de apreciación a la hora de aplicar dicha disposición, no pueden permitir que éstos impongan criterios tan estrictos que hagan prácticamente imposible la impugnación por las organizaciones de defensa del medio ambiente de las acciones u omisiones a las que se alude en esa disposición (apdos. 47 y 48).

\section{PLANTEAMIENTO DEL ESTUDIO}

Nuestra misión en las páginas siguientes consistirá justamente en analizar, dando una particular importancia a la jurisprudencia de la Sala Tercera del Tribunal Supremo, los «criterios» con que el Estado español ha concretado la norma procesal del art. 9.3 del Convenio de Aarhus, o sea: estudiar cuál es el régimen jurídico patrio de la acción popular en asuntos medioambientales. Para ello, acometeremos en primer término (2) una caracterización general del instituto, explicando de un modo especial (2.1) su alcance - en vía administrativa y ante la jurisdicción contencioso-administrativa- y (2.2) delimitándolo de otros títulos de legitimación contemplados en el art. 19.1 de la LJCA. A continuación, podremos proceder a deslindar la acción popular medioambiental tanto objetivamente, mediante la definición conceptual de (3) los asuntos que pueden constituir su objeto según el art. 22 de la Ley 27/2006, como subjetivamente, indicando cuáles son (4) sus potenciales actores de conformidad con el art. 23.1 de la misma ley. Al abordar esta última cuestión, prestaremos una atención singular a (4.1) la problemática relativa al acceso al beneficio de justicia gratuita en virtud del art. 23.2 de la Ley 27/2006. El trabajo se cierra con el habitual capítulo de (5) conclusiones en el que vamos a reflexionar acerca del futuro próximo de la acción popular en asuntos medioambientales.

\section{CARACTERIZACIÓN GENERAL DEL INSTITUTO}

El Tribunal Supremo ha reiterado que «el ordenamiento jurídico no concede una acción pública en materia de protección del medio ambiente, ni siquiera en la reciente Ley 27/2006, [...] la cual, en su art. 22, sólo otorga acción popular a las personas jurídicas sin ánimo de lucro y sólo cuando 
cumplen los requisitos de su art. $23 »^{14}$. En la Sentencia de 7 de junio de 2013, la Sala recuerda asimismo que «lo esencial» en las acciones públicas ${ }^{15}$ «es que se permita el ejercicio de la acción a cualquier "ciudadano" " y que, precisamente por este motivo, «la propia Ley 27/2006, de 18 de julio, en su exposición de motivos, duda de su naturaleza al señalar que se introduce una "especie de acción popular"» $\left(\mathrm{FJ} 7^{\circ}\right)$.

Es bien sabido, en efecto, que el art. 19.1 h) de la LJCA dispone que está legitimado ante el orden jurisdiccional contencioso-administrativo "cualquier ciudadano, en ejercicio de la acción popular, en los casos expresamente previstos por las Leyes». De este modo, la LJCA prevé la acción popular de "modo genérico» y, al mismo tiempo, se abstiene de establecerla en casos concretos, «remitiendo a decisiones normativas concretas que en todo caso a) han de ser establecidas por ley (por norma con rango de ley, como exige el precepto al hablar de "Leyes" con mayúscula), y b) "expresamente" o de manera inequívoca» ${ }^{16}$.

La «decisión normativa» tomada, al amparo del apartado h) del art. 19.1 de la LJCA, por los arts. 22 y 23 de la Ley 27/2006, tiene claras diferencias con el art. 39 de la Ley 30/2014, de 3 de diciembre, de Parques Nacionales,

14 Sentencia de 16 de mayo de 2007 (FJ 4º); Sentencia de 7 de junio de 2013 (FJ 7o); Sentencia de 16 de junio de 2016 (FJ 6o); Sentencia de 7 de julio de 2017 [FJ 4º, apartado A)].

15 En la doctrina, Á. Ma Ruiz de Apodaca Espinosa (2007), «La acción pública ambiental: una necesidad satisfecha parcialmente por la Ley 27/2006, de 18 de julio", Revista Aranzadi de derecho ambiental, 11, págs. 51-64 opta, en el mismo título de su artículo, por la fórmula «acción pública ambiental», si bien recalcando que las expresiones «acción pública» $\mathrm{y}$ «acción popular» son sinónimas, al igual que R. Fernánez Valverde (2007), «La integración de las exigencias del Convenio de Aarhus en el sistema procesal español a través de la Ley 27/2006», en B. Lozano Cutanda y F. Gutiérrez-Alviz Conradi, Examen de la nueva Ley de acceso a la información, participación pública y acceso a la justicia en materia de medio ambiente, "Estudios de Derecho Judicial», 137 (págs. 35-114), Madrid: Consejo General del Poder Judicial. Centro de Documentación Judicial, pág. 103. La misma posición parece asumirse en S. Muñoz Machado (dir.) (2016), Diccionario del español jurídico, Barcelona: Espasa, al definir la expresión «acción pública» como «la legitimación que ostenta cualquier ciudadano, en ejercicio de la acción popular, para interponer un recurso contencioso-administrativo en materia urbanística y en determinados supuestos relativos al patrimonio histórico-artístico y al medioambiente».

16 J. A. Santamaría Pastor (2010), La Ley reguladora de la Jurisdicción Contencioso-administrativa. Comentario, Madrid: Iustel, pág. 235. Véase también, con carácter monográfico, M. ${ }^{a}$ D. Rego Blanco (2005), La acción popular en el derecho administrativo y en especial, en el urbanistico, Sevilla: Instituto Andaluz de Administración Pública. 
de conformidad con el cual «será pública la acción para exigir ante los órganos administrativos y los tribunales de justicia la estricta observancia de los preceptos relativos a los parques nacionales existentes en esta ley, en las leyes declarativas de los parques nacionales y en las disposiciones que se dicten para su desarrollo y aplicación». La misma diferencia se observa también con las acciones públicas reconocidas, por ejemplo ${ }^{17}$, para perseguir las infracciones en materia de caza [art. 47.1 b) de la Ley 1/1970, de 4 de abril, de Caza], para defender los bienes integrantes del Patrimonio Histórico Español (art. 8.2 de la Ley 16/1985, de 25 de junio, del Patrimonio Histórico Español), para proteger el dominio público marítimo-terrestre (art. 109.1 de la Ley 22/1988, de 28 de julio, de Costas) o para hacer respetar las determinaciones de la ordenación territorial y urbanística [arts. 5 f) y 62 del Real Decreto Legislativo $7 / 2015$, de 30 de octubre, por el que se aprueba el texto refundido de la Ley de Suelo y Rehabilitación Urbana] ${ }^{18}$. Siguiendo esta senda, podríamos agregar múltiples normas autonómicas ${ }^{19}$, si bien no está nada claro que las comunidades autónomas tengan competencias suficientes en legislación procesal —a

17 B. Lozano Cutanda (2009), Derecho ambiental administrativo, 10 edición, Madrid: Dykinson, pág. 269; B. Lozano Cutanda, A. Lago Candeira y L. F. López Álvarez (2014), Tratado de derecho ambiental, Madrid: Centro de Estudios Financieros, pág. 328; C. Tolosa Tribiño (2010), «Proceso contencioso y medio ambiente: cuestiones procesales», Revista Jurídica de Castilla y León, 21, págs. 13-49 (pág. 16); J. Jordano Fraga (2007), «Análisis de la Ley 27/2006 en cuanto al acceso a la justicia, en especial el principio de legitimación en los contenciosos ambientales», en B. Lozano Cutanda y F. Gutiérrez-Alviz Conradi, Examen de la nueva Ley de acceso a la información, participación pública y acceso a la justicia en materia de medio ambiente, "Estudios de Derecho Judicial», 137 (págs. 115-140), Madrid: Consejo General del Poder Judicial. Centro de Documentación Judicial, págs. 132-133.

18 Sentencia de 25 de junio de 2008, FJ 50: «[...] así como en el ámbito urbanístico la nueva Ley 8/2007, de 28 de mayo, del Suelo ha supuesto un nuevo impulso y tendencia hacia la publicidad, participación y transparencia, igualmente es evidente que, en el ámbito medioambiental —que es el ahora nos ocupa—, la tendencia en tal sentido es mucho más intensa y visible. Posiblemente, la tradicional consideración del carácter, más general, de los valores medioambientales, frente a los urbanísticos, ha sido la causa determinante de dicha intensidad hacia la publicidad y participación ciudadana en relación con el medio ambiente». Estas reflexiones son reproducidas en la Sentencia de 25 de mayo de 2010 (FJ 4º), que además insiste en dotar de plena vigencia y aplicabilidad al art. 9.3 del Convenio de Aarhus.

19 Así, la Sentencia de 25 de mayo de 2010 alude a la disposición adicional 1a de la Ley 16/1995, de 4 de mayo, Forestal y de Protección de la Naturaleza de la Comunidad de Madrid, según la cual «será pública la acción de exigir ante los órganos administrativos competentes la observación de lo establecido en esta Ley y en las normas que puedan 
la luz del art. 149.1.6 a de la Constitución — para regular nuevas acciones públicas o populares ${ }^{20}$.

En definitiva, como afirmara la Sala Tercera en su Sentencia de 16 de junio de 2016, «se observa sin dificultad» que la acción popular en asuntos medioambientales «no es la acción pública que admiten algunos sectores de nuestro ordenamiento jurídico» $(\mathrm{FJ} \mathrm{6o})^{21}$. Se trata, insistimos, de «una acción pública peculiar, porque tiene unos límites hasta ahora desconocidos en el ejercicio de la acción pública. Baste señalar que su ejercicio depende de la concurrencia de una serie de requisitos» (FJ 70). En su Sentencia de 29 de abril de 2016, la Sala incluso afirma que los arts. 22 y 23 de la Ley 27/2006 «más bien» contemplan «una habilitación legal» que no una verdadera "acción popular» ${ }^{22}$.

dictarse para su desarrollo y aplicación» (FJ 4º). Para una selección no exhaustiva de las mismas, véase C. Tolosa Tribiño (2010: 28).

20 Ma P. Teso Gamella (2009), «Legitimación y acción popular. Novedades jurisprudenciales», Cuadernos de Derecho Público, 36, págs. 71-89 (pág. 75); J. Jordano Fraga (2007: 134); C. Tolosa Tribiño (2010: 28-29); B. Lozano Cutanda et al. (2014: 330-331). Particularmente categórico se muestra en este sentido J. A. Santamaría Pastor (2010: 235-236) al afirmar que «es notorio que diversas normas autonómicas han establecido otros supuestos de acción pública (sobre todo, en materia de medio ambiente)», pero «no las mencionamos ni tenemos en cuenta [...] porque tales previsiones son jurídicamente irrelevantes [...]. Al formar parte de la legislación procesal, la determinación de los supuestos de acción pública es competencia exclusiva del Estado [...], por lo que las previsiones que se hagan en la normativa autonómica carecen de todo efecto vinculante sobre los jueces y tribunales». Sigue faltando, sin embargo, un pronunciamiento del Tribunal Constitucional al respecto, ya que la STC 151/2012, de 5 de julio, acabó en nada. En aquel asunto, en efecto, la Sección $2^{\text {a }}$ de la Sala de lo Contencioso-Administrativo del Tribunal Superior de Justicia del País Vasco cuestionaba la constitucionalidad del art. 3.4 de la Ley 3/1998, de 27 de febrero, de Protección General del Medio Ambiente, según el cual «será pública la acción para exigir el cumplimiento de lo previsto en esta ley, tanto en vía administrativa como jurisdiccional». El Alto Tribunal, empero, termina por declarar la extinción de la cuestión planteada por desaparición de su objeto al haberse formulado desistimiento por la parte recurrente en el procedimiento a quo.

21 Según B. Lozano Cutanda et al. (2014: 330), debe entenderse que las acciones públicas sectoriales mantienen su vigencia «en cuanto se trata de legislación especial no derogada por la Ley 27/2006, de carácter general». De hecho, afirma J. Jordano Fraga (2007: 138), "otra interpretación nos llevaría al absurdo — contrario al principio pro actione y al art. 45 de la Constitución - de haber aprobado una ley de acceso a la justicia en materia de medio ambiente para impedir y restringir dicho acceso».

22 En la doctrina, A. Peñalver i Cabré (2007), «Nuevos instrumentos para la aplicación de la legislación ambiental ante la inactividad administrativa. De las acciones ciuda- 
Reaparece aquí de nuevo la exposición de la Ley 27/2006, en concreto el fragmento en donde se afirma que "consagra [...] una legitimación legal para tutelar un interés difuso como es la protección del medio ambiente» ${ }^{23}$. Y ello porque — volvemos a la Sentencia de 29 de abril de 2016 — «esta habilitación legal no opera de forma semejante a las acciones públicas, como atribución de legitimación a cualquier ciudadano sin necesidad de invocar títulos o intereses específicos, sino que limita esa legitimación a las entidades que cumplan las condiciones que ahí se detallan» (FJ 30).

Por su lado, algún autor ha llegado a la conclusión de que este instituto procesal debería denominarse "acción pública de carácter corporativo»" ${ }^{24}$, mientras que otros han optado por incluirla —al menos en un plano idealdentro de las citizen suits ${ }^{25}$, o sea: las «acciones ciudadanas» que, en el ordenamiento jurídico norteamericano, "permiten a cualquier persona demandar a otras personas (ya sean públicas o privadas) por determinados incumplimientos de las leyes ambientales» ${ }^{26}$.

La Sala Tercera, en su primeriza Sentencia de 25 de junio de 2008 (FJ $5^{\circ}{ }^{27}$, identificó con singular nitidez una de las principales finalidades de esta nueva acción popular mediante cita de un fragmento de la exposición de mo-

danas (citizen suits) al Convenio de Aarhus», Revista de Administración Pública, 172, págs. 439-485 (pág. 481) anticipó que «la correcta inserción de la Ley 27/2006 en el marco constitucional y legal obligará a la jurisprudencia a hacer una interpretación de esta "especie de acción popular" de determinadas ONG ambientales como una legitimación por habilitación legal, al no poderse menoscabar la legitimación del resto de las ONG ambientales al ser titulares de un interés legítimo colectivo al medio ambiente». Este mismo autor ha vuelto posteriormente sobre el tema en otros trabajos como (2013), «Las pretensiones en el contencioso-administrativo para la efectiva protección de los intereses colectivos», Revista de Administración Pública, 190, págs. 149-194; y (2014), "El derecho humano al medio ambiente y su protección efectiva», Revista Vasca de Administración Pública, 99-100, págs. 2333-2357. A su vez, B. Lozano Cutanda (2009: 270) también se refiere a la existencia de «una habilitación legal general en nuestro ordenamiento de legitimación de las ONG ambientales para actuar en defensa del medio ambiente». En cambio, J. Jordano Fraga (2007: 122) y C. Tolosa Tribińo (2010: 25) aluden a «una legitimación restringida a sujetos colectivos y no a todos los sujetos colectivos». Sentencia de 8 de junio de 2015 (FJ 30); Sentencia de 7 de julio de 2017 (FJ 5o).

24 B. Lozano Cutanda (2009: 269-271). J. Jordano Fraga (2007: 127-128) también alcanza la conclusión de que «la Ley 27/2006 configura la resurrección de una legitimación corporativa».

25 A. Peñalver i Cabré (2007: 478-481).

26 A. Peñalver i Cabré (2007: 440 y 442).

27 Sentencia de 7 de julio de 2017 [FJ 6º apartado A)]. 
tivos de la Propuesta de Directiva del Parlamento Europeo y del Consejo sobre el acceso a la justicia en materia de medio ambiente ${ }^{28}$ :

[...] la no aplicación del Derecho medioambiental se debe con demasiada frecuencia a que la capacidad procesal para recurrir se limita a las personas directamente afectadas por la infracción. De ahí que una forma de mejorar la aplicación sea garantizar que las asociaciones representativas de protección del medio ambiente tengan acceso a los procedimientos administrativos o judiciales de medio ambiente. La experiencia práctica adquirida en el reconocimiento de la capacidad procesal de las organizaciones no gubernamentales de medio ambiente demuestra que ha servido para reforzar la aplicación del Derecho medioambiental (epígrafe 1.1) ${ }^{29}$.

En su posterior Sentencia de 7 de junio de 2013, la misma Sala insistiría en que la:

[...] extensión legal de la acción pública [art. 19.1 h) de la LJCA] a determinados ámbitos se realiza en atención a los diferentes y sensibles intereses en juego, porque la acción pública lo que pretende es «robustecer y reforzar la protección de determinados valores especialmente sensibles, haciendo más eficaz la defensa de los mismos, ante la pluralidad de intereses concurrentes» [...]. Se considera, en definitiva, que la relevancia de los intereses en juego demanda una protección más vigorosa y eficaz que la que puede proporcionar la acción de los particulares afectados, por lo que ha de extenderse la misma a cualquier ciudadano que pretenda simplemente que se observe y se cumpla la ley $\left(\mathrm{FJ} 5^{\circ}\right)^{30}$.

$28 \mathrm{COM}(2003)$ 624. Procedimiento 2003/0246/COD. Esta propuesta fue elaborada justamente para desarrollar lo previsto por el art. 9.3 del Convenio de Aarhus. Aunque se presentó por la Comisión el 24 de octubre de 2003 (DOUE C 96 de 21 de abril de 2004, pág. 22) y llegaría a ser aprobada con enmiendas por la Comisión de Medio Ambiente, Salud Pública y Política del Consumidor del Parlamento Europeo (18 de marzo de 2004) y dictaminada favorablemente por el Comité Económico y Social Europeo (29 de abril de 2004) (DOUE C 117 de 30 de abril de 2004, págs. 55-57), al final se frustró - en palabras de la propia Sentencia de 25 de junio de 2008- «por la falta de convergencia de los distintos enfoques de los Estados miembros» (FJ $5^{\circ}$ ). Una década después, en efecto, la propuesta sería retirada por «obsoleta» por la propia Comisión (DOUE C 153 de 21 de mayo de 2014, pág. 3).

29 C. Tolosa Tribiño (2010: 22). Este autor considera que se trata de «una reflexión sumamente interesante en cuanto [...] pone de relieve cómo la protección del medio ambiente depende, entre otros factores, de la regulación de las normas que permiten el acceso a la justicia».

$30 \quad M^{a}$ P. Teso Gamella (2009: 74). 


\section{DELIMITACIÓN CON OTROS SUPUESTOS DE LEGITIMACIÓN}

Aunque se hallen reguladas conjuntamente en el mismo título IV de la Ley 27/2006, no podemos confundir la acción popular en asuntos medioambientales (arts. 22 y 23) con la posibilidad que el art. 20 reconoce al «público que considere que un acto o, en su caso, una omisión imputable a una autoridad pública ha vulnerado los derechos que le reconoce esta Ley en materia de información y participación pública» para interponer recursos administrativos y/o para acudir a la vía contencioso-administrativa. Con este precepto de la Ley 27/2006 se desarrollan las previsiones de los apdos. 1 — sobre el acceso a la información sobre el medio ambiente ${ }^{31}$ - y 2 - sobre la participación del público en las decisiones relativas a actividades específicas ${ }^{32}$ - del art. 9 del Convenio de Aarhus, mientras que el origen de la acción popular se halla en su art. 9.3. Es muy elocuente, en este sentido, un pronunciamiento contenido en la Sentencia de 7 de julio de 2017:

[...] la Ley 27/2006 no limita el denominado «derecho de acceso a la justicia en materia ambiental» a supuestos de vulneración de lo dispuesto en esa Ley en materia de información y participación pública pues su art. 22 prevé la acción popular en asuntos medioambientales, permitiendo el ejercicio del derecho de acceso a la justicia en materia ambiental con la posibilidad de impugnar administrativa y jurisdiccionalmente la actividad de la Administración que vulnere la normativa medioambiental, el cual es un reflejo de lo previsto en el artículo 9.3 del Convenio de Aarhus [FJ 6º apartado B)].

Pero también es esencial diferenciar convenientemente los títulos de legitimación activa ante la jurisdicción contencioso-administrativa previstos en los apartados b) y h) del art. 19.1 de la LJCA. Mientras que este último consiste, como ya hemos visto, en el «ejercicio de la acción popular, en los casos expresamente previstos por las Leyes», el primero se refiere a "las corporaciones, asociaciones, sindicatos y grupos y entidades [...] que resulten afectados o estén legalmente habilitados para la defensa de los derechos e intereses legítimos colectivos ${ }^{33}$.

31 Sentencia de 25 de junio de 2008 (FJ 5º); Sentencia de 16 de junio de 2016 (FJ $7^{\circ}$ ).

32 Sentencia de 25 de junio de 2008 (FJ 5º); Sentencia de 25 de mayo de 2010 (FJ 4º); Sentencia de 7 de julio de 2017 [FJ 6º, apartado A)].

33 Así las cosas, al poco tiempo de la entrada en vigor de la Ley 27/2006, la Sala Tercera, en su Sentencia de 29 de noviembre de 2006, avaló la legitimación activa de la Asociación para la Defensa del Desarrollo Ecológico Sostenible para impugnar el Acuerdo de 6 de mayo de 1999 del Consejo de Gobierno de la Comunidad de Madrid, por el que se resuelve la discrepancia relativa a un proyecto de extracción de granito y se excluyen 
Son muy interesantes, al respecto, las reflexiones vertidas por la Sala en su ya mentada Sentencia de 25 de junio de 2008:

La especial y decidida protección del medio ambiente por parte del art. 45 de la Constitución Española, y el carácter amplio, difuso y colectivo de los intereses y beneficios que con su protección se reportan a la misma sociedad — como utilidad substancial para la misma en su conjunto-, nos obliga a configurar un ámbito de legitimación en esta materia en el que las asociaciones como la recurrente debemos considerarlas como investidas de un especial interés legítimo colectivo, que nos debe conducir a entender que las mismas, con la impugnación de decisiones medioambientales [...], no están ejerciendo exclusivamente una defensa de la legalidad vigente, sino que están actuando en defensa de unos intereses colectivos que quedan afectados por el carácter positivo o negativo de la decisión administrativa que se impugna [...].

Esto es, [...] la especial significación constitucional del medio ambiente amplía, sin duda, el marco de legitimación de las asociaciones como la recurrente, las cuales no actúan movidas exclusivamente por la defensa de la legalidad sino por la defensa de unos cualificados o específicos intereses que repercuten en la misma, y, con ella, en toda la sociedad a quien también el precepto constitucional le impone la obligación de la conservación de los mismos.

La recurrente, pues, al impugnar los actos frente a los que se dirigieron las pretensiones objeto del presente recurso, actuó — al hacerlo con la finalidad con que lo hizo - debidamente legitimada y en el marco de legitimación permitido por el artículo 19.1 b) de la LJCA (FJ 4º).

En esta misma línea, la Sala de lo Contencioso-administrativo del Tribunal Supremo, en su Sentencia de 31 de marzo de 2009, ha reconocido la legitimación de la Plataforma en Defensa da Ría de Arousa por cuanto «asume la defensa de los derechos e intereses legítimos colectivos que resultan afectados por las resoluciones administrativas que autorizan instalaciones de almacenamiento de productos petrolíferos y productos químicos en el muelle del Ferrazo del Puerto de Villagarcía de Arousa» (FJ 5o). En esta misma Sentencia, la Sala distingue con acierto entre el título de legitimación propio de corporaciones, asociaciones, sindicatos y otros grupos con la acción popular en asuntos medioambientales regulada por los arts. 22 y 23 de la Ley 27/2006 al afirmar, como ya hemos avanzado, que el art. 9 del Convenio de Aarhus «vincula al órgano judicial que resuelva recursos contencioso-administrativos

determinados proyectos del trámite de evaluación de impacto ambiental, todos ellos localizados en Cadalso de los Vidrio, en base al art. 19.1 b) de la LJCA, pero ańadiendo que «hoy deberíamos — además — tener en cuenta la vigente Ley 27/2006, de 18 de julio» [FJ 6º, apdo. B)]. 
en materia de medio ambiente, en razón de la naturaleza y el carácter específico de los intereses medioambientales, a que realice una interpretación no restrictiva del art. 19.1 b) de la LJCA, basada en los principios que informan el mencionado Tratado internacional medioambiental, que asegure la tutela judicial efectiva de los intereses medioambientales postulados» ( $\left.\mathrm{FJ} 5^{\circ}\right)^{34}$.

La necesaria diferenciación entre los apdos. b) y h) del art. 19.1 de la LJCA volvería a ponerse de manifiesto en la Sentencia de 1 de diciembre de 2009, dictada por el Pleno de la Sala Tercera:

[...] no es preciso en el presente asunto entrar a considerar en qué forma resulta aplicable la jurisprudencia de esta Sala, con todos sus matices y precisiones, respecto de la legitimación para impugnar resoluciones administrativas de personas jurídicas cuya actividad u objetivos puedan resultar afectados por tales resoluciones [art. 19.1 b) de la LJCA]. En efecto, en caso de autos resulta de directa aplicación la Ley 27/2006 invocada por la entidad recurrente, cuyos arts. 22 y 23 le otorgan indiscutiblemente legitimación para interponer el recurso contencioso-administrativo a quo que formuló contra las resoluciones administrativas referidas $\left(\mathrm{FJ} \mathrm{2}^{\circ}\right)^{35}$.

Ahora bien, que los motivos de una determinada impugnación se sustenten «sobre razones medioambientales [...] no significa que para que tal alegato pueda esgrimirse ante los Tribunales haya de ejercitarse, necesariamente, la acción pública medioambiental [...]. Sobre todo si tenemos en cuenta el carácter transversal de la materia medioambiental que se proyecta sobre gran parte de los ámbitos sectoriales de la actuación administrativa». Así lo afirmaría la Sala Tercera en las dos sentencias que dictó en fecha 4 de julio de 2014 a propósito de los recursos formulados contra el Real Decreto 355/2013, de 17 de mayo, por el que se aprueba el Plan Hidrológico de la Demarcación Hidrográfica del Guadalquivir. Tanto en un caso como en el otro, la Sala consideró que la entidad recurrente - la Asociación de Regantes de Andalucía y la Unión de Pequeños Agricultores y Ganaderos de Andalucía, respectivamente- ostentaba un «interés legítimo» en el sentido del art. 19.1 a) de la LJCA en la medida en que «no le es indiferente el resultado del proceso, sino que obtendrá un beneficio o perjuicio, según sea o no estimado el recurso en los puntos en los que la norma resulta perjudicial a sus intereses, y por ello ha formulado la presente impugnación. Téngase en cuenta, a los efectos de valorar el interés

34 Sentencia de 15 de septiembre de 2009 (FJ 20); Sentencia de 17 de mayo de 2011 (FJ $\left.2^{\circ}\right)$. También se aportan tales argumentos, aunque con consecuencias distintas, en la Sentencia de 23 de marzo de 2010 (FJ 2o).

35 Sentencia de 7 de julio de 2017 [FJ 4º, apdo. C); FJ 6º, apdo. A)]. 
que tiene en el contenido del Plan Hidrológico impugnado, que la recurrente participó en las fases de preparación y elaboración de esquema relativos al citado plan» $\left(\mathrm{FJ} \mathrm{2}{ }^{\circ}\right)^{36}$. Esta tesis fue avanzada por la doctrina científica, según la cual el nuevo régimen jurídico de la Ley 27/2006 no supone «una derogación de la legitimación existente que puede ser más favorable». Así, «tanto si existen acciones populares como otras formas de legitimación general previstas en la LJCA, entendemos que esas normas debe considerarse prevalentes ${ }^{37}$.

\section{EL ALCANCE DE LA ACCIÓN}

El art. 22 de la Ley 27/2006, de 18 de julio, alude al «recurso contencioso-administrativo previsto en la LJCA», pero también a "los procedimientos de recurso regulados en el Título VII de la LRJPAC», hoy sustituido por el título V de la LPAC. Por ello, la acción pública en asuntos medioambientales alcanza tanto la vía administrativa como la vía contencioso-administrativa. Se trata, según la doctrina, de los cauces que más posibilidades ofrecen «para ejercitar acciones dirigidas a la protección del entorno. La mayoría de los litigios de carácter ambiental se sustancian en la actualidad ante la Administración o la jurisdicción contencioso-administrativa, lo que responde al papel preponderante de los poderes públicos y del derecho administrativo en la ordenación y protección de los bienes ambientales» ${ }^{38}$.

En este punto cabe recordar que, en el marco de la LPAC, solamente pueden promover la revisión de actos en vía administrativa — bien a través de la revisión de oficio (art. 106.1), bien a través de los recursos administrativos (art. 112.1) - aquellos que tienen la consideración de «interesados» en el sentido el art. 4.1 de la LPAC. Dicho precepto no contiene una previsión semejante al art. 19.1 h) de la LJCA, pero en su apdo. 2 contempla lo siguiente: «[...] las asociaciones y organizaciones representativas de intereses económicos y sociales serán titulares de intereses legítimos colectivos en los términos que la

36 De hecho, como advierte el Tribunal, «la recurrente no ha ejercitado la acción popular medioambiental prevista en el art. 22 de la Ley 27/2006 [...]. Nótese que en la propia demanda se hace cita, a propósito de la legitimación, del art. 19 de la LJCA» (FJ 20). Ciertamente, es la Administración General del Estado que «contesta a la demanda alegando que la recurrente carece de legitimación para impugnar el Plan Hidrológico del Guadalquivir porque no es titular de ningún derecho ni de interés legítimo, puesto que los motivos de su impugnación son únicamente medioambientales, y no concurren los requisitos previstos en el Ley 27/2006» (FJ 1º). Dicha alegación, por las razones que quedan expuestas, es descartada.

37 C. Tolosa Tribiño (2010: 28).

38 B. Lozano Cutanda et al. (2014: 327). 
Ley reconozca». Parece claro, entonces, que la proyección de la acción popular medioambiental de la Ley 27/2006 en el procedimiento administrativo halla su anclaje en este art. 4.2 de la LPAC. Sea como fuere, no se confunde en ningún caso con la facultad que el art. 62.1 de la LPAC concede a «cualquier persona, en cumplimiento o no de una obligación legal», para "denunciar» a «un órgano administrativo la existencia de un determinado hecho que pudiera justificar la iniciación de oficio de un procedimiento administrativo ${ }^{39}$.

Una vez abierta la vía jurisdiccional ante los órganos del orden contencioso-administrativo, «un fin de control de legalidad» — ha argumentado la Sala Tercera en su Sentencia de 16 de junio de 2016-, "no encuentra cobertura en la acción pública que regula el art. 23, en relación con los arts. 22 y 18 de la Ley 27/2006» (FJ 7o). Por lo tanto, la acción pública medioambiental se halla limitada en cuanto a su alcance material por razón de su propia finalidad:

[...] tal reconocimiento de la legitimación para recurrir (legitimación ad processum) no significa - ha matizado la Sala en su Sentencia de 16 de enero de 2018 a propósito de la impugnación por este cauce del Plan de Desarrollo de la Red de Transporte de Energía Eléctrica 2015-2020 - que la recurrente puede suscitar cuestiones ni aducir motivos de nulidad ajenos al ámbito medioambiental al que se circunscribe aquella legitimación. Por tanto, y aun no concurriendo causa para la inadmisión del recurso, habrán de ser desestimados aquellos motivos de anulación basados en la vulneración de la Ley 24/2013, de 26 de diciembre, del Sector Eléctrico [...] por venir referidos a cuestiones que no están comprendidas en el ámbito de la legitimación resultante de lo dispuesto en los arts. 18, 22 y 23 de la Ley 27/2006, de 18 de julio, y dado que la recurrente tampoco ha justificado debidamente la imbricación de esas vulneraciones que alega de la normativa del sector eléctrico con la materia medioambiental que constituye su título de legitimación $\left(\mathrm{FJ} 2^{\circ}\right)^{40}$.

39 Como explica J. A. Santamaría Pastor (2010: 236), «la denuncia o puesta en conocimiento de hechos ante la Administración nunca ha estado sometida a requisito alguno y es, por tanto, de uso general».

40 La Sala argumenta que «la legitimación que en el art. 22 de la Ley 27/2006 se reconoce a las personas jurídicas sin ánimo de lucro que cumplan los requisitos del art. 23 no se confiere de forma omnicomprensiva, para que puedan intervenir y formular impugnaciones en toda clase de materias, sino de forma más acotada o limitada, esto es, para denunciar a las autoridades públicas "que vulneren las normas relacionadas con el medio ambiente enumeradas en el art. 18.1". Pues bien, la enumeración de materias contenida en ese art. 18.1 al que se remite el art. 22 de la Ley 27/2006 hace referencia a ámbitos de actuación y regulaciones de diversa índole [...], pero en esa amplia relación del art. 18.1 no se hace referencia alguna a la regulación del sector eléctrico. Siendo ese el régimen normativo de la legitimación de las personas jurídicas 
La legitimación ante la jurisdicción contencioso-administrativa que confiere la acción popular en asuntos medioambientales también alcanza la fase ejecutiva. Así se puso de manifiesto en el caso protagonizado por la Asociación Plataforma para la Defensa del Río Castril Siglo XXI, que por escrito de fecha 19 de mayo de 2010 promovió incidente de ejecución de la Sentencia de 24 de noviembre de 2009, con la cual la propia Sala Tercera había declarado la nulidad del Real Decreto 1419/2005, de 25 de noviembre, por el que se adoptan medidas administrativas excepcionales para la gestión de los recursos hidráulicos y para corregir los efectos de la sequía en las cuencas hidrográficas de los ríos Guadiana, Guadalquivir y Ebro, tras estimarse el recurso interpuesto por una entidad local y por varias mercantiles. Dicho incidente es resuelto por el Auto de 4 de febrero de 2011, en el que la Sala Tercera debe hacer frente primeramente a la alegación de la Abogacía del Estado en el sentido de que «la Asociación personada carece de legitimación [...], ya que no intervino como parte en el pleito ni tiene la condición de parte afectada» (FJ 5o). La contestación del Alto Tribunal es que «la Asociación personada para pedir la ejecución de la Sentencia reúne las condiciones establecidas en los citados arts. 22 y 23 de la mentada Ley 27/2006, de 18 de julio y, por tanto, tiene el carácter de afectada para instar la ejecución de la sentencia al amparo de lo dispuesto en el art. 104.2 de la Ley de esta Jurisdicción» $(\mathrm{FJ} \mathrm{60})^{41}$.

regulado en los arts. 22 y 23 de la Ley 27/2006, de 18 de julio, puestos en relación con el art. 18 de la propia Ley, debemos concluir que la asociación de vecinos recurrente está legitimada para impugnar el documento de planificación energética que nos ocupa por entender que dicho instrumento vulnera de la Ley 9/2006, de 28 de abril, sobre evaluación de los efectos de determinados planes y programas en el medio ambiente» (FJ 20).

41 Se funda esta decisión en el precedente de la Sentencia de 23 de abril de 2010: Ecologistas en Acción-CODA solicitaba la personación en el incidente de ejecución de los pronunciamientos que anularon en parte la revisión del PGOU de Madrid de 1997, el Tribunal Superior de Justicia deniega esta petición, pero la Sala Tercera accede a ella tras recordar que «es pública la acción para exigir la observancia de la legislación urbanística y de los planes [...]. La trascendencia de la protección de la legalidad urbanística que ha llevado al legislador a ampliar la legitimación que tal reconocimiento general comporta [...] debe tener alguna consecuencia en el recurso contenciosoadministrativo tanto en la fase declarativa como en la ejecución de lo decidido. Y es que tal legitimación conferida para la protección urbanística ha de extenderse y proyectarse también, para ser consecuentes con las razones que avalan tal reconocimiento, a la fase de ejecución en la medida que pretenda que lo acordado en sentencia firme sea cumplido. Las mismas razones, por tanto, que permiten su presencia en el proceso para obtener una resolución judicial sobre el asunto, alcanzan a la ejecución para hacer que efectivamente se verifique lo decidido» (FJ 70). 


\section{DEFINICIÓN DEL CONCEPTO «ASUNTOS MEDIOAMBIENTALES»}

El objeto de la acción popular en asuntos medioambientales se define, en el art. 22 de la Ley 27/2006, a partir de las dos notas siguientes:

II. Tiene que dirigirse, tanto en vía administrativa como ante la jurisdicción contencioso-administrativa, contra $\operatorname{actos}^{42}$ y omisiones ${ }^{43}$ que resulten «imputables» a cualquiera de las «autoridades públicas» que se hallen englobadas en la definición legal del art. 2.4.1 de la Ley 27/2006:

a) El Gobierno de la Nación y los órganos de gobierno de las Comunidades Autónomas.

b) La Administración General del Estado, las Administraciones de las Comunidades Autónomas, las Entidades que integran la Administración local y las Entidades de Derecho Público que sean dependientes o estén vinculadas al Estado, a las Comunidades Autónomas o a las Entidades locales.

c) Los órganos públicos consultivos.

d) Las Corporaciones de derecho público y demás personas físicas o jurídicas cuando ejerzan, con arreglo a la legislación vigente, funciones públicas, incluidos Notarios y Registradores de la Propiedad, Mercantiles y de Bienes Muebles.

Sin embargo, quedan exceptuados, por remisión del segundo párrafo del art. 22 al art. 2.4.2 de la misma Ley 27/2006, los actos y omisiones imputables a «las personas físicas o jurídicas cuando asuman responsabilidades públicas, ejerzan funciones públicas o presten servicios públicos relacionados con el medio ambiente bajo la autoridad de cualquiera de

42 Incluida la vía de hecho, según R. Fernández Valverde (2007: 103) y J. Jordano Fraga (2007: 128).

43 De acuerdo con C. Tolosa Tribiño (2010: 26), también es posible por esta vía el recurso contra la inactividad de la Administración, «pues esta es la vía específica para actuar contra las «omisiones» de la administración contrarias a la ley». Véase, in extenso, sobre esta cuestión, B. Lozano Cutanda, «Análisis general de la Ley 27/2006 de acceso a la información, participación pública y acceso a la justicia en materia de medio ambiente», en B. Lozano Cutanda y F. Gutiérrez-Alviz Conradi, Examen de la nueva Ley de acceso a la información, participación pública y acceso a la justicia en materia de medio ambiente, «Estudios de Derecho Judicial», 137 (págs. 169-206), Madrid: Consejo General del Poder Judicial. Centro de Documentación Judicial, págs. 204-205. 
las entidades, órganos o instituciones» enumerados en el ya referido art. $2.4 .1^{44}$.

III. El acto o la omisión que se recurra debe vulnerar las normas relacionadas con el medio ambiente que, según lo dispuesto por el art. 18.1 de la Ley 27/2006, se refieran a protección de las aguas, protección contra el ruido, protección de los suelos, contaminación atmosférica, ordenación del territorio rural y urbano y utilización de los suelos, conservación de la naturaleza, diversidad biológica, montes y aprovechamientos forestales, gestión de los residuos, productos químicos, incluidos los biocidas y los plaguicidas, biotecnología, otras emisiones, vertidos y liberación de sustancias en el medio ambiente, evaluación de impacto medioambiental, acceso a la información, participación pública en la toma de decisiones y acceso a la justicia en materia de medio ambiente y aquellas otras materias que establezca la normativa autonómica.

El supuesto de hecho más sorprendente que ha sido incluido, hasta la fecha, en este concepto de "asuntos medioambientales» que acabamos de estudiar ha sido la concesión de un indulto al condenado como autor de un delito contra la ordenación del territorio (Real Decreto 853/2013, de 31 de octubre). En efecto, en su Sentencia de 8 de junio de 2015, la Sala Tercera recuerda su anterior doctrina sobre «la legitimación activa del ofendido por un delito para impugnar en esta jurisdicción el real decreto de concesión de un indulto» para concluir:

[...] el enjuiciamiento que puede promover el ofendido por el delito no alcanza, desde luego, a la concesión o denegación del indulto, pues el ejercicio del derecho de gracia constituye una facultad potestativa que no es susceptible de control por esta jurisdicción, salvo en lo relativo a los elementos reglados de la gracia, pero $[\ldots]$ «lo que no es ajeno a la víctima es que, ya que ha de aceptar el perdón público, este se ajuste a lo previsto en la Ley», y este es el interés que

44 De hecho, el art. 2.4.3 de la Ley 27/2006 dispone que «quedan excluidos del concepto de autoridad pública las entidades, órganos o instituciones cuando actúen en el ejercicio de funciones legislativas o judiciales. En todo caso, cuando actúen en el ejercicio de funciones legislativas o judiciales, quedan excluidos del ámbito de aplicación de esta Ley las Cortes Generales, las Asambleas Legislativas de las Comunidades Autónomas, el Tribunal Constitucional, los juzgados y tribunales que integran el Poder Judicial, el Tribunal de Cuentas u órganos de fiscalización externa de las Comunidades Autónomas». 
asiste a la asociación recurrente en este caso, a la que el legislador encomienda la tutela del interés difuso de la protección del medio ambiente, que no permite combatir en esta jurisdicción la decisión misma de concesión o no del indulto, pero sí en cambio que el mismo se produzca con sujeción a los aspectos formales establecidos por la Ley (FJ 30).

Es cierto que la misma Sala, en su Sentencia de 7 de junio de 2013, entendió que «el ejercicio de la acción pública urbanística no puede entenderse bloqueado o cercenado cuando se impugna un acto no urbanístico», pero para que en tales circunstancias dicha acción pudiera llegar a prosperar afirmó que es preciso que el acto impugnado «se encuentre esencialmente vinculado a los usos del suelo y se invoque una norma legal que impida el uso que reconoce la concesión» (FJ 6º). El hándicap de la Sentencia de 8 de junio de 2015 radica entonces en la ausencia de una vinculación clara entre el indulto concedido por el Real Decreto 853/2013 y el medio ambiente, como se pone de manifiesto en el voto particular formulado por dos magistrados de la Sala: «[...] la legitimación legal que el art. 22 reconoce a este tipo de asociaciones - leemos en este voto - no tiene otro alcance que la de habilitarlas para accionar contra actos de las Administraciones lesivos al medio ambiente en alguna de estas materias [en alusión al art. 18.1] "sin necesidad de invocar ningún derecho o interés lesionado"». Ahí radica, como decíamos, el punto neurálgico de la discrepancia: "[...] el acto aquí recurrido no se refiere a ninguna de estas materias, específica y taxativamente recogidas en el precitado art. 18.1 de la Ley 27/2006, sino que es un acuerdo del Consejo de Ministros de concesión de indulto parcial de la pena privativa de libertad impuesta en una Sentencia firme condenatoria de un órgano jurisdiccional penal ${ }^{45}$.

Esto no obstante, en su reciente Sentencia de 7 de julio de 2017, la Sala Tercera ha propuesto precisamente como ejemplo el caso resuelto por la Sentencia de 8 de junio de 2015 para concluir que «la especial significación constitucional del medio ambiente amplía, sin duda, el marco de legitimación de las asociaciones como la recurrente, las cuales no actúan movidas exclusivamente por la defensa de la legalidad sino por la defensa de unos cualificados o específicos intereses que repercuten en la misma, y, con ella, en toda la sociedad a quien también el precepto constitucional le impone la obligación de la conservación de los mismos» (FJ 50). En la práctica, empero, el caso resuelto por la Sentencia de 7 de julio de 2017 presenta unos mimbres mucho más razonables: «[...] el objeto del procedimiento es la impugnación de resoluciones

45 M. Pons Portella (2016), «La acción popular medioambiental en el control jurisdiccional de la gracia de indulto: el caso del Real Decreto 863/2013», Actualidad Jurídica Ambiental, 62, págs. 7-33. 
administrativas que no reconocen la legitimación de la Fundación Oceana en [...] un procedimiento sancionador dirigido a [...] sancionar [...] una serie de vertidos en el medio marino». Con todo acierto, la Sala considera que «no tiene sentido que si la Ley 27/2006 permite la impugnación por la Fundación Oceana de una resolución administrativa que culmina un procedimiento sancionador por vulnerar la legislación medioambiental, no permita que dicha entidad sea parte en el procedimiento donde se ventila ese asunto lo que, a su vez, imposibilitaría su impugnación puesto que la Fundación Oceana no recibe la notificación de la resolución» [FJ 6 $6^{\circ}$, apartado A)].

La interpretación del art. 18.1 de la Ley 27/2006 ha sido abordada por la misma Sala Tercera en su Sentencia de 16 de junio de 2016:

[...] para entender adecuadamente este precepto no puede utilizarse un criterio de inclusión nominativo de sectores de legislación, ya que existen materias [...] que no están comprendidas en la enumeración bajo este criterio, pero sin embargo puede tener, en determinadas facetas, un alto impacto en el medio ambiente, y en concreto en la protección de los suelos, las aguas, la utilización de los suelos. Existe, además, un título transversal como es la evaluación de impacto ambiental, que afectará aquellas actividades que se encuentren afectadas por la obligación de evaluación de impacto ambiental.

Según la doctrina, ciertamente, no era "necesario» este «listado exhaustivo de materias de contenido ambiental dado que se corre el riesgo de que si alguna de esas materias no se incluyen en alguna ley de contenido ambiental, la acción pública quede fuera. Hubiese bastado con hacer una referencia genérica a la infracción de las normas de contenido ambiental con las tradicionales exclusiones para esta limitada acción pública» ${ }^{46}$. Así, volviendo a los pronunciamientos de la Sentencia de 16 de junio de 2016, el Alto Tribunal rechaza «descartar a priori que determinadas actuaciones administrativas [...] puedan comportar una lesión a los sectores enunciados en el art. 18 de la Ley 27/2006", dado que lo determinante para identificar correctamente el objeto de la acción popular en asuntos medioambientales es saber si la acción o la omisión que se impugna "pudiera afectar a algunos de los sectores concernidos», es decir: su "trascendencia» directa o indirecta "para la protección del medio ambiente» $\left(\mathrm{FJ} \mathrm{6}^{\circ}\right)$.

46 Ruiz de Apodaca Espinosa (2007). También se hacen eco de estas críticas C. Tolosa Tribińo (2010: 27) y J. Jordano Fraga (2007: 132), quien reprocha «esta forma de legislación por remisión». 


\section{LOS SUJETOS DE LA ACCIÓN POPULAR EN ASUNTOS MEDIOAMBIENTALES}

En virtud del art. 23.1 de la Ley 27/2006, de 18 de julio ${ }^{47}$, el recurrente que haga uso de la acción popular en asuntos medioambientales debe ser una persona jurídica sin ánimo de lucro que tenga entre los fines acreditados en sus estatutos la protección del medio ambiente en general o la de alguno de sus elementos en particular [apartado a) $]^{48}$, que se haya constituido legalmente al menos dos años antes del ejercicio de la acción y que venga ejerciendo de modo activo las actividades necesarias para alcanzar los fines previstos en sus estatutos [apartado b)] y que, según estos mismos estatutos, desarrolle su actividad en un ámbito territorial que resulte afectado por la actuación o, en su caso, omisión administrativa [apartado c) $]^{49}$.

En su primeriza Sentencia de 16 de mayo de 2007, la Sala Tercera ya alcanzó la conclusión de que la acción popular en asuntos medioambientales no puede ser utilizada válidamente por un particular (FJ 40). Así lo declararía expresamente el Alto Tribunal en su posterior Sentencia de 7 de junio de 2013: «el recurrente en la instancia es una persona física, y respecto de estas la ley no reconoce la acción pública medioambiental ${ }^{50}$. En efecto, debe tratarse

47 Sentencia de 1 de diciembre de 2009: «[...] debe señalarse, además, que la Ley 27/2006, de 18 de julio, aparte de sus efectos como lex posterior, modifica expresamente el Real Decreto Legislativo 1302/1986, de 28 de junio, de Evaluación de Impacto Ambiental [disposición final $1^{\mathrm{a}}$, apartado 1] y la Ley 16/2002, de 1 de julio, sobre Prevención y Control Integrados de la Contaminación [disposición final 2a, apartado 1], en el sentido de considerar "personas interesadas" en los procedimientos en ellas regulados a quienes cumplan los requisitos establecidos por el art. 23 de la propia Ley 27/2006 que hemos visto" $\left(\mathrm{FJ} 2^{\circ}\right)$. En la actualidad se trata, respectivamente, del art. $5.1 \mathrm{~g}$ ) $2^{\circ}$ de la Ley 21/2013, de 9 de diciembre, de Evaluación Ambiental y del art. 3.19 b) del Real Decreto Legislativo 1/2016, de 16 de diciembre, por el que se aprueba el texto refundido de la Ley de prevención y control integrados de la contaminación. J. Jordano Fraga (2007: 122-123) también menciona la Ley 9/2006, de 28 de abril, sobre evaluación de los efectos de determinados planes y programas en el medio ambiente, derogada por la Ley 21/2013.

48 Según B. Lozano Cutanda (2009: 270), la exacta formulación del art. 23.1 a) de la Ley $27 / 2006$ no obliga a que la protección del medio ambiente sea el «fin principal» de la entidad.

49 J. Jordano Fraga (2007: 124-128) afirma que «es ciertamente llamativo el establecimiento del criterio de la conexión territorial. La inspiración en este caso es el Derecho anglosajón», lo que "contrasta con nuestra jurisprudencia que se ha caracterizado por el reconocimiento de una amplia legitimación en contenciosos ambientales».

50 Sentencia de 7 de julio de 2017 [FJ 6o, apartado A)]. 
de «asociaciones dedicadas a la defensa del medio ambiente» (FJ $7^{\circ}$ ) que cumplan las condiciones de la Ley 27/2006 .

Entre dichas "condiciones» merece ser destacado el requisito temporal del art. $23.1 \mathrm{~b}$ ), que exige — como ya hemos avanzado- que las «personas jurídicas sin ánimo de lucro» que ejerciten la acción popular en asuntos medioambientales «se hubieran constituido legalmente al menos dos años antes del ejercicio de la acción ${ }^{52}$. De acuerdo con la doctrina científica, este requisito está «dirigido a impedir que se constituyan asociaciones ad hoc cuando se produce algún conflicto o desastre ambiental, pero hay que señalar que en estos casos si se constituyen asociaciones de afectados podrán recurrir igualmente, pues la LJCA reconoce legitimación a "las personas físicas o jurídicas que ostenten un derecho o interés legítimo" [art.19.1 a)]»"53. Sea como fuere, según lo explicado en la Sentencia de 29 de abril de 2016, a los efectos del art. 23.1 b) de la Ley 27/2006, «la fecha relevante para el reconocimiento de la legitimación [...] es cuando se produce su inscripción en el Registro, al así indicarlo el art. 10.2 de la Ley Orgánica 1/2002, de 22 de marzo, reguladora del Derecho de Asociación». El Alto Tribunal también precisa, por último, que «la norma exige este requisito temporal de dos años a cualesquiera entidades, sin excepciones o salvedades derivadas de sus mayores o menores dimensiones o más o menos limitado ámbito de actuación» (FJ 3º).

La carga procesal de demostrar el cumplimiento de todos estos requisitos exigidos por el art. 23 de la Ley 27/2006 compete al recurrente, como se pone de manifiesto en la Sentencia de 25 de junio de 2014: la Sala Tercera inadmite el recurso contencioso-administrativo interpuesto por el partido político Izquierda Unida contra el otorgamiento de varios permisos de investigación de hidrocarburos tras constatar que:

[...] tampoco cabe reconocer la legitimación para recurrir por tratarse del ejercicio de la acción popular en materia de medio ambiente derivada del

51 Sentencia de 29 de abril de 2016 (FJ 30).

52 El Reglamento (CE) no 1367/2006 del Parlamento Europeo y del Consejo, de 6 de septiembre de 2006, relativo a la aplicación, a las instituciones y a los organismos comunitarios, de las disposiciones del Convenio de Aarhus, en su art. 11.1 c), también exige, para poder formular una «solicitud de revisión interna de actos administrativos» (art. 10) y, luego, un «recurso ante el Tribunal de Justicia» (art. 12), que la correspondiente organización no gubernamental «haya existido durante más de dos años». Citado por la Sentencia de 29 de abril de 2016 (FJ $3^{\circ}$ ).

53 B. Lozano Cutanda (2009: 270). J. Jordano Fraga (2007: 123-124) y C. Tolosa Tribińo (2010: 25-26) apuntan que esta exigencia, que critican por su «carácter restrictivo", es de origen francés. 
apartado h) del art. 19 LJCA. La actora nada dice en su demanda ni en su escrito de conclusiones acerca de que entre sus fines estatutarios se encuentre específicamente la protección del medio ambiente, pues silencia cualquier alegación y argumento en este sentido. Y por otra parte tampoco menciona el cumplimiento de los requisitos mencionados en los arts. 22 y siguientes de la Ley 27/2006 (FJ 60 $)^{54}$.

\section{LA PROBLEMÁTICA DEL BENEFICIO DE ASISTENCIA JURÍDICA GRATUITA}

El art. 9.4 del Convenio de Aarhus estipula que los procedimientos previstos en su apdo. 3, entre otros, «deberán ser objetivos, equitativos y rápidos sin que su costo sea prohibitivo». En desarrollo de esta previsión, el art. 23.2 de la Ley 27/2006, de 18 de julio, ha dispuesto que «las personas jurídicas sin ánimo de lucro a las que se refiere el apartado anterior tendrán derecho a la asistencia jurídica gratuita en los términos previstos en la Ley 1/1996, de 10 de enero, de Asistencia Jurídica Gratuita». Esta cuestión «no es de índole menor», ha señalado la doctrina, "dado que el coste económico que puede suponer un proceso, en especial por las pruebas periciales, puede constituir un obstáculo importante para que la participación y el acceso a la justicia sea real y efectiva cuando se trata de entidades sin ánimo de lucro que se enfrentan a la Administración o a empresas privadas " ${ }^{5}$.

Justamente, el Comité del Cumplimiento del Convenio de Aarhus, tras haber recibido sendas comunicaciones contra el Gobierno de España, formuló un informe que serviría de base para que durante la Cuarta Reunión de las Partes del Convenio, celebrada en Moldavia el mes de julio de 2011, se adoptara la Decisión IV/9(f) sobre el cumplimiento por parte de España de sus obligaciones convencionales en cuanto al acceso a la justicia ambiental y, en lo que aquí nos ocupa, a la práctica judicial en relación con la concesión de asistencia jurídica gratuita a las ONG ambientales ${ }^{56}$. En su informe sobre el

54 Sin embargo, el magistrado José Manuel Bandrés Sánchez-Cruzat discrepa sobre este extremo de la Sentencia porque, "conforme a lo dispuesto en los arts. 22 y 27 de la Ley 27/2006 [...], y el art. 6 del Convenio [...], la circunstancia [...] de que la defensa letrada de dicho partido político no haga en sus escritos procesales de demanda y conclusiones ninguna referencia al cumplimiento de los requisitos exigidos, no puede derivar en negar su acceso a la justicia en defensa de los intereses medioambientales». B. Lozano Cutanda et al. (2014: 330).

56 Véase todo el procedimiento, con los múltiples documentos emitidos durante el mismo, en el siguiente enlace: https://bit.ly/2yTiopb (consultado el 6 de marzo de 2018). 
particular, el Ministerio de Medio Ambiente reconoce que «la cuestión fundamental que se plantea aquí es cómo interpretar la remisión que el art. 23.2 de la Ley 27/2006, de 18 de julio, realiza a la Ley de Asistencia Jurídica Gratuita» y admite, asimismo, que existen «dos corrientes de interpretación claramente definidas», tanto en la práctica forense como en la doctrina: la primera considera que únicamente puede concederse el beneficio en cuestión a aquellas entidades que, aparte de reunir los requisitos del art. 23.1 de la Ley 27/2006, también respeten lo previsto por el apdo. c) del art. 2 de la Ley 1/1996, según el cual solo tienen acceso a dicho beneficio las asociaciones de utilidad pública $y$ las fundaciones inscritas "cuando acrediten insuficiencia de recursos para litigar»; la segunda, por el contrario, afirma que el aludido art. 23.2 «realiza una atribución expresa e incondicional del derecho a la asistencia jurídica gratuita a las ONG ambientales». El informe que estamos comentando también constata que:

[...] las Comisiones de Asistencia Jurídica Gratuita, como órganos responsables, en su correspondiente ámbito territorial, de efectuar en cada caso el reconocimiento de este derecho, vienen entendiendo de manera casi unánime que las personas jurídicas sin ánimo de lucro a las que se refiere la Ley 27/2006, de 18 de julio, en su art. 23 [...] deben cumplir obligatoriamente los requisitos generales establecidos en la Ley 1/1996 para acceder a la justicia gratuita. Así, se observa cómo son sistemáticamente denegadas las peticiones de acceso a la justicia gratuita por parte de entidades que, o bien no acreditan la insuficiencia de medios o recursos para litigar, o bien no adjuntan la correspondiente declaración de utilidad pública. Las impugnaciones de estas decisiones interpuestas ante los Juzgados de lo Contencioso obtienen normalmente la misma respuesta.

Ahora bien, el propio informe también detecta la primeriza aparición de «importantes resoluciones en las que, partiendo de una interpretación pro actione, se reconoce el derecho a la asistencia jurídica gratuita a asociaciones ambientales por el hecho de concurrir en ellas los requisitos para interponer la acción popular ambiental de la Ley 27/2006». Esta corriente jurisprudencial, por aquel entonces todavía incipiente, ha sido confirmada rotundamente por la Sala Tercera del Tribunal Supremo en su Auto de 16 de enero de 2018: la Asociación Vallisoletana de Afectados por Antenas de Telecomunicaciones recurre una resolución denegatoria de la Comisión Central de Asistencia Jurídica Gratuita y la Sala, tras criticar «la motivación estereotipada del acto impugnado» (FJ $1^{\circ}$ ), afirma que:

[...] la exigencia del art. 2 de la Ley 1/1996 para las personas jurídicas allí reseñadas en general y para el ejercicio de acciones de cualquier clase - que acrediten insuficiencia de recursos para litigar - no es aquí exigible. De lo 
contrario resultaría innecesaria o inútil la previsión expresa del art. 23.2 para el ejercicio de acciones por las personas jurídicas sin ánimo de lucro de este precepto. En consecuencia, por aplicación estricta del art. 23.2 - que en otro caso sería superfluo-, procede dicho reconocimiento $\left(\mathrm{FJ} 2^{\circ}\right)$.

Este importante pronunciamiento del Alto Tribunal debe ser matizado en dos sentidos: primero, con su Auto de 30 de octubre de 2014, la propia Sala recordó que la jurisprudencia sobre el art. 9.4 del Convenio «se limita a señalar la necesidad de que los costes del proceso no sean excesivamente onerosos, condición que no cabe atribuir a la tasa judicial ${ }^{57}$ singularmente y aisladamente considerada en la medida en la que [...] su regulación nacional impide que se la pueda considerar como un obstáculo que dificulte el acceso al proceso» (FJ 4\%); segundo, con otro Auto de 29 de octubre de 2015, la Sala también precisó que a una entidad que tenga reconocida la asistencia jurídica gratuita en virtud del art. 23.2 de la Ley 27/2006 «no le es aplicable la previsión contemplada en el art. 36.2 de la Ley 1/1996 que solo obliga al pago de las costas en el caso de que el que tenga reconocido dicho beneficio venga a mejor fortuna en el plazo de tres años, toda vez que ello solo se refiere a los que han obtenido tal derecho por carecer de recursos suficientes para litigar» $(\mathrm{FJ} \mathrm{30})$.

\section{v. CONCLUSIÓN}

La acción popular en asuntos medioambientales regulada por los arts. 22 y 23 de la Ley 27/2006, de 18 de julio, ha servido para llevar ante los tribunales de justicia desde una infracción leve de vertido de aguas residuales hasta el cumplimiento de la declaración de impacto ambiental de un aeropuerto, la declaración de utilidad pública de una central térmica de ciclo combinado o las medidas administrativas excepcionales adoptadas para corregir los efectos de la sequía de 2005. Estos ejemplos sirven para poner de manifiesto que dicha acción ha demostrado ser un instrumento procesal fructífero para lograr uno de los «deseos» expresados por las partes del Convenio de Aarhus: «[...] que el público, incluidas las organizaciones, tengan acceso a mecanismos judiciales eficaces para que los intereses legítimos estén protegidos y para que se respete la ley».

57 Se refiere a la tasa el ejercicio de la potestad jurisdiccional regulada en el título I de la Ley 10/2012, de 20 de noviembre, por la que se regulan determinadas tasas en el ámbito de la Administración de Justicia y del Instituto Nacional de Toxicología y Ciencias Forenses. 
Una parte de la doctrina ha criticado el modo como ha sido incorporado por España el art. 9.3 del indicado Convenio, al argüir que la regulación positiva de la Ley 27/2006 es restrictiva en exceso: los reproches se han formulado sobre todo contra el listado de «normas relacionadas con el medio ambiente» del art. 18.1 y contra las exigencias que el art. 23.1 impone a los sujetos legitimados. De hecho, este último aspecto supone que la acción popular en asuntos medioambientales no sea tal, dado que — siguiendo el art. $19.1 \mathrm{~h}$ ) de la LJCA — no puede ejercitarla "cualquier ciudadano", sino más bien una legitimación o habilitación para las ONG ambientales. Algún autor, sin embargo, ha destacado la prudencia de esta solución "por cuanto el ejercicio de la acción pública por los particulares se presta con frecuencia a abusos y chantajes, tal y como se ha puesto de manifiesto a menudo en el ámbito urbanístico, ofreciendo en este sentido las asociaciones dedicadas a la protección ambiental mayores garantías de ejercicio de la acción para fines puramente ambientales" ${ }^{58}$.

Para que la acción popular en asuntos medioambientales pueda seguir siendo útil en el futuro al efecto de lo previsto en el Convenio de Aarhus, será preciso mantener la interpretación jurisprudencial del art. 18.1 de la Ley 27/2006 que rechaza emplear en su aplicación «un criterio de inclusión nominativo de sectores de legislación", asumiendo que el medio ambiente tiene un carácter transversal aunque, tal como también ha señalado el Tribunal Supremo, la acción que estudiamos no tenga propiamente «un fin de control de legalidad». Además, deberá consolidarse la posición favorable al reconocimiento del beneficio de asistencia jurídica gratuita a las asociaciones que invoquen el art. 23.2 de la Ley 27/2006 con la finalidad de asegurar que realmente pueda accederse a la justicia ambiental «sin que su costo sea prohibitivo».

58 B. Lozano Cutanda et al. (2014: 330). 
